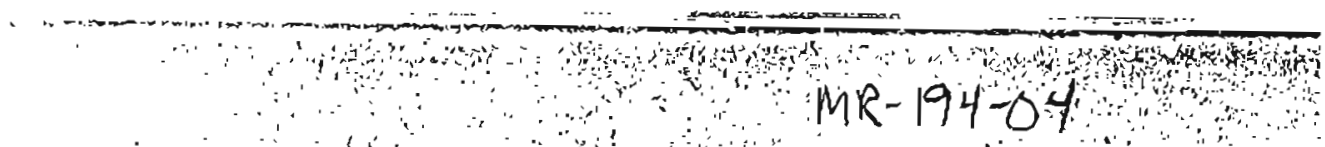

PROGRESS OF LODE MINING

\title{
IN INTERIOR ALASKA
}

1230

By

Earl R. P1lgrim

General Summary of Operations -1

Improvements in Power . . . . $\quad . \quad . \quad \therefore$

Mining Operations:

Cleary Hill Alaska:Mines Co o Wyoming Mine.....". . . .

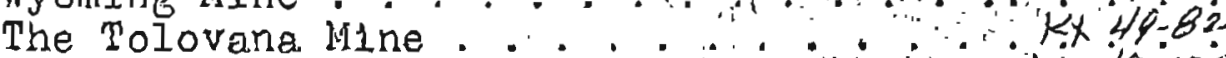

Newsboy MLne....... . ........... $49-122$

Soo 0la1m. . . . . . . . .

Borovich and Stevens (Eva Quarta Mine) Kx 58-37

Eva Greek Group. . .

Wandering Jew W. MoConn and J" MoCann) Kx $58200^{\circ}$

Mohawk Mintng Company . . ....

Irtshman Group . . . . $\quad \begin{array}{r}58-35 \\ k 8-145\end{array}$

Sanfurd Group. . . . $\therefore .4 \%$

H1 Yu group ........ . .

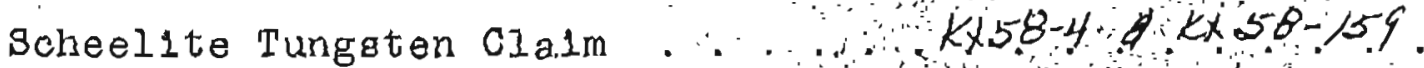

1

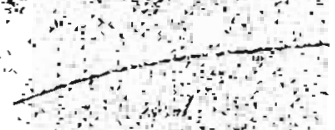

$\therefore$ and

Nenana District - Liberty. Beli Mine

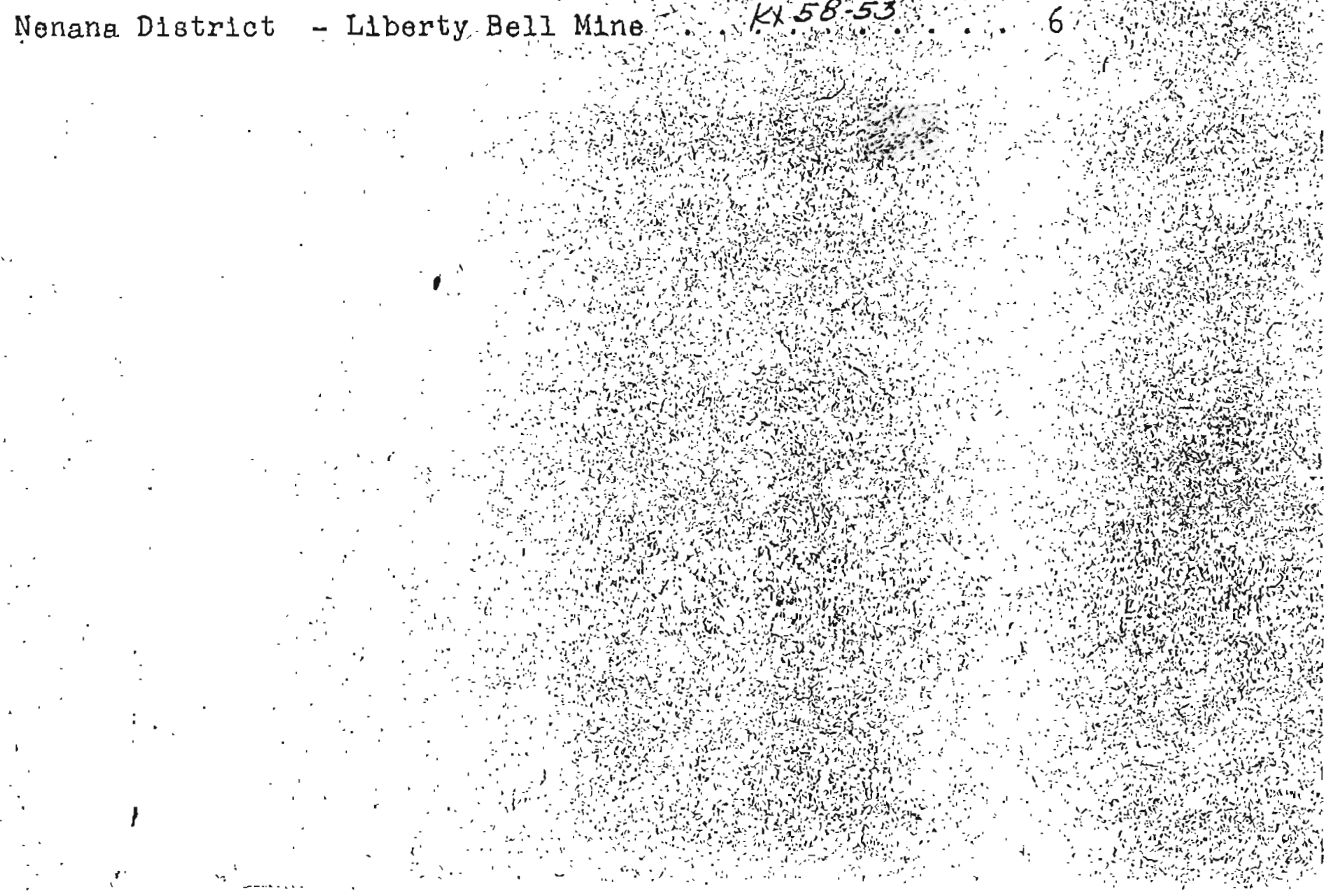





\section{PRCGRESS OP LODE HIITHG}

\section{IN INTEIRIOR ALASKA}

1230

By

Earl R. P1Igrin

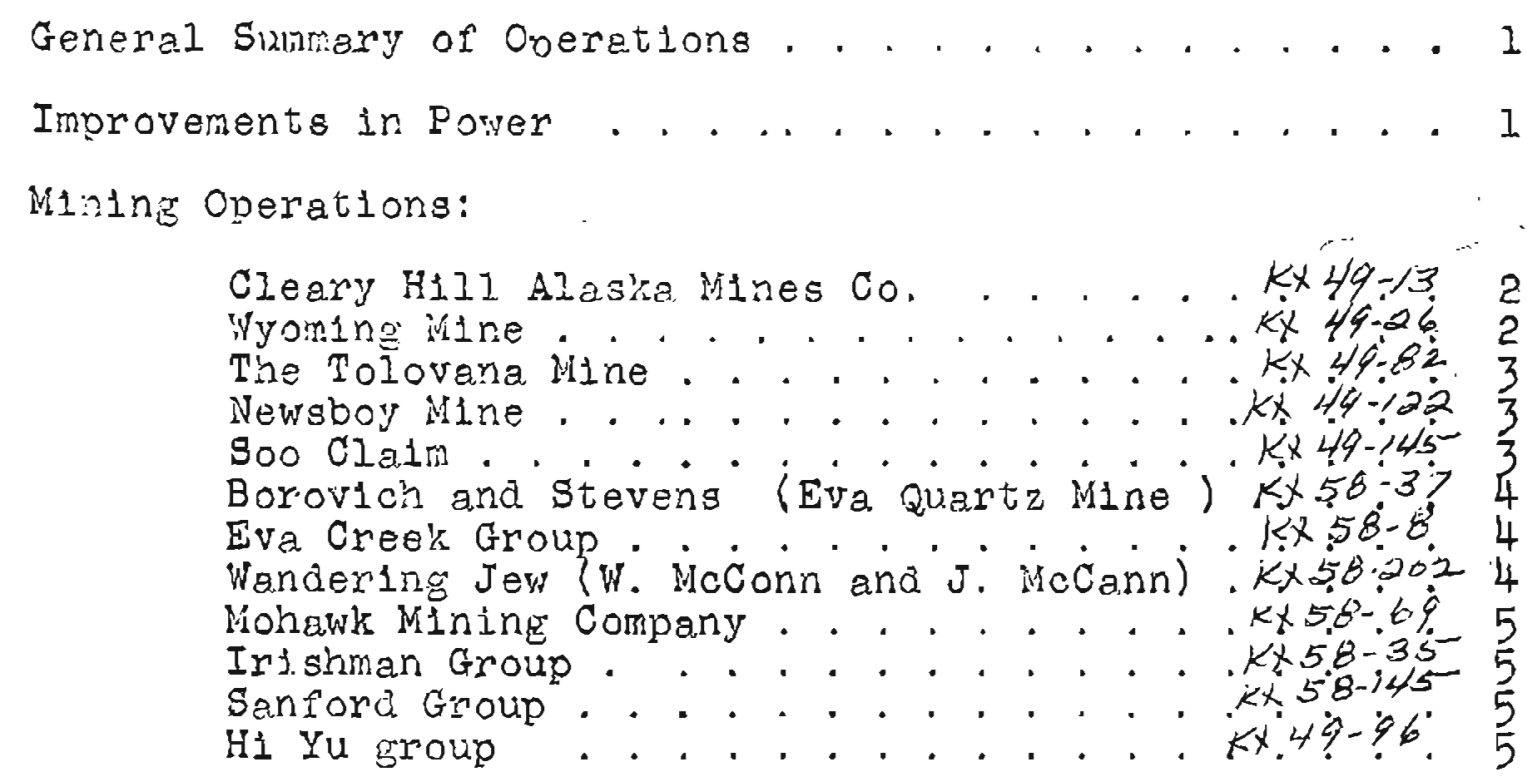

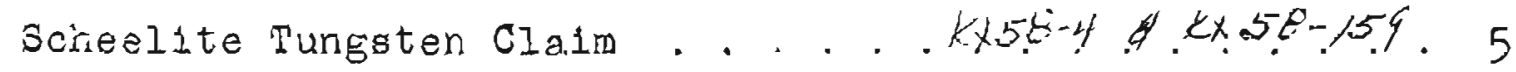

Nenana District - Liberty Eell Mine . kx 5E-53... . 6 


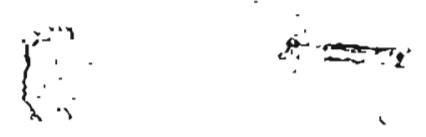

Progress of Lode lining in Interior Alaske 1930.

Lode mining in the Interior during 1930 had one of the best seasons in a number of years in spite of the fact that several mines which operated in 1929 were idle during all or the greater part of the year. There ware no new discoveries of promise rade ouring the year. The close of the year was marked by a resumption of work on one of the regular gald producers which was idle durins most of. 1929 and 1930 because of litigation; by the reentrance into the ranks of the producers by the femous Free Gold mine, freatest producer of the Fairbanks district; by the resumption of mork on the Liberty Bell mine in the Nenana district Totatlanika Region and the Tolorana and Newsboy mines in the Fairbanks district. Interest also ras show in an effort to open up one of the tungsten mines, non-operative since 1917. In a period marked by general depression and idieness, it was cheering, that practically all ouartz miners in the Interior rorked steadily through both the summer and winter. Present activities forecast whe most successul year for the goldilode-minessinge 1915. The proposed increase of freight rates on the Alaska Railroad between Sevard and. Feirbanks vill undoubtedly have a dampening effect on the rnineral investigations being made in the Interior by several groups seeking investments.

General sumnary of Operations.

Fairbanks District

Number of mines operated
Namber of mills operated


early years of lode mining in the Fairbanks district, mood was used for fuel in all plants. Later as the available birch and spruce became scarce and more costly, coal was used. Coal delivered at the nearby mines in the rairbanks district, costs from 6.00 to 12.00 per ton. Fuel consumption, of the lignite coal mined in the lienana Field, in the small power plants arounts to approximately .01 tons or from 6 cents to 12 cents per horsepower-hour. Deisel oil delivered at the mines costs from 20 cents to 25 cents per gallon. Fuel consumption of the deisel engine for these small plants equals approximately.05 gallons or from 1 cent to $1 \frac{1}{4}$ cents per horsepower-hour. other plants are contemplating the change from steam to deisel porer during the present year.

\section{Eine operations.}

a. $4+49$ The cleary Hill Alaska lisines gfompany operating the iree Gold

Rive

foremost producer of the diftrict. 30 , again taking rank as the the year was obtalned from qbove the Penrose tunnel on the shoot found in 1929. This mine has/a past production of close to 2.10 .2$, $\$ 1,000,000$. The company is bperatjng a 5istamp mill and a $9 \times 8$ Ingersol-Rand compressor, driven by steam power.

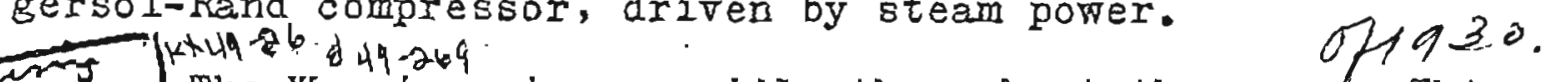
Fhemping me wyoming mine was idle throughout the year, This mine is situated on Bedrock Creek south of the Free Gold mine. It id opened

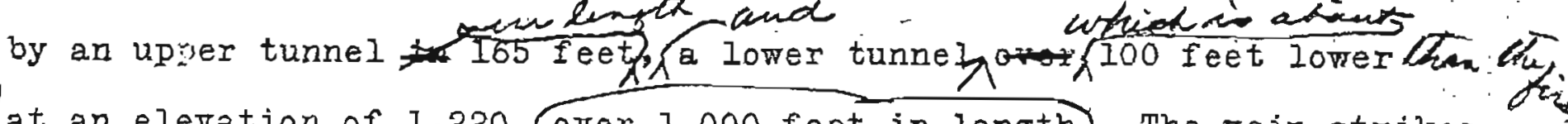
andat an elevation of 1,220, Over 1,000 feet in length The vein strikes ㄱ. $65^{\circ}$ E. and dips $30^{\circ}$ to $60^{\circ}$ ST. Wiost of the vein has been stoped above this tunnel. It is now planned to drive a tunnel on a parallel vein 150 feet north anf upan which little pork has been done. A crosscut can then be ariven to reach the kiyoming vein at increased depth. The plant coneists of a $7 \times 10$ Blake-type crusher, a 4-foot Herman $\tilde{n}_{\mathrm{b}} \mathrm{bll} \mathrm{mill}$ and amalgamation plates. The mill is ariven by a 10-lip. Gasoline engine. A 120-cubic foot Garafner-Denver aix compressor is driven by a s-cylinder automobile engine. 


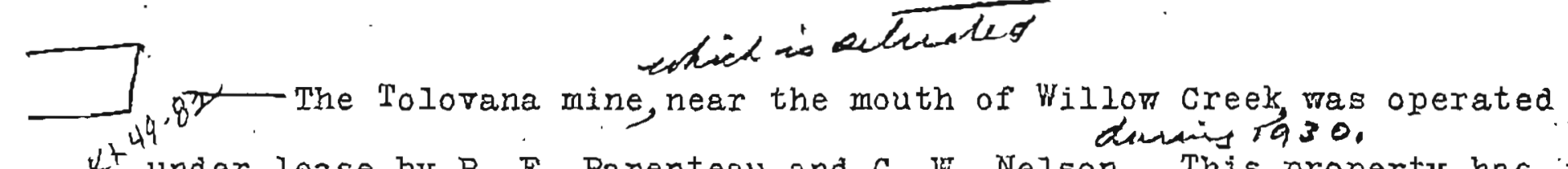
$L^{t}$ under lease by R. E. Parenteau and C. W. Nelsony This property has been idle for a number of years except for a few spismodic attempts to operait. The lessees have located the extension of the rein on a the pest side of Willow Creek and op by a tunnel 160 feet in length. The vein here strikes from N. $65^{\circ}$ E. to N. $30^{\circ}$ E. and if dips srom $30^{\circ}$ to $60^{\circ} \mathrm{SE}$. About 50 tons of ore millea from this tunnel 4 in 1930 showed good values. The tunnel $]_{1}$ at an elevation of 1,300 feet, Ejives littie depth below the ridge between Willow and Cleary creeks. The ground appears to be considerably shattered and faulted, perhaps ง due to the shallow depth. The vein shows from 1 to 12 inches in, width rith an average of 7 inches of banded white quarty considerably crushed in placel. The plant is equipped with a 2-stamp Nisson mill steam-driven.

$449-122-$ The Nersboy mine, idie since 1913 due to inability to fing $\mathrm{k}^{\text {th }}$ the faulted extension of the vein, ras optioned to a group known as the Newsboy Development Company, and rork started late in the 1930 redean year to $p_{\lambda}$ the old workings. This vein, ${ }_{A}$ one of the early producers of the district, is located on the saddle betmeen the heads of Cleary and Little illdorado creeks. The property consists of the $\mathcal{N}$ Newsboy, Lucky Iad, Red FlaE, and Wise like claims. The rein strikes N. $40^{\circ} \mathrm{E}$. and dips $73^{\circ} \mathrm{NH}$, , and is opened by a shaft over 300 feet $N$ deep following the vein. The vein has been stoped for about 200 reet northeast of the shaft above the 215-foot level, and ror about the D: same distance southwest of the shaft. Levels are turned off at the f $60,115,165,215$, and 315-foot torizons The vein there stoped raneed from $2_{h}^{\text {fect }} 14$ feet in ridth, with an average of about 5 feet. A complicated system of faults has cut off the vein on both ends. The faults strike northeast and aip to the northmest. The property has a 5-stanp Joshua Hendy nill steam-ariven 3oceted about 4,000 feet north of the shaft and 600 feet lover in elevation. 14t 41455 The soo claim formerly a part of the spalding mine and later
described as the lleath and Kerno/mone was worked in 1930 by Heath ano

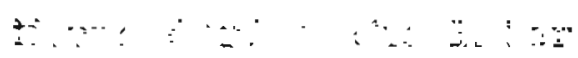


lierns during the early part pof the year and by $c$. H. Hapkins curing the latter part of the year. Iflning was carpied on, on the Heath and Kerns vein in the stope abope the 110 foot level east of the shait and also irom the shaft close to the surface. Some ore was mined from $\hat{W}$ the Alpha claim southeast ff the soo blaim. Wackwitz vrothers on a lease took out a few tons of good ore from the Heath and at a point above the 500 feot tunnel close to the surface. George Pittoff ras preparing to operate a sub lease on the rild Rose vein during 1931 .

$1458.3^{1}$ Borovicin and stevens operated during the year of the property known as the Iva Ruartz ming betpeen Ready Bullion and Pster Ereeks. This property is developins into a lasge low Erede mine showing Widths of ovex 40 feet of 1 pr gradg ore, in a shear zone of crushed shinist. Sampling of some of the 1930 developments showed the following; 56 feet feet of crogscut on No. 2 vein at No. 6 raise averagea 2.50 per ton. 46 feet of crosscut on No." 3 vein from Raise Ho. 4 averageo $\$ 5.8 \%$ per ton. k58.6 The Eva Creek Eroup was qorked in a small way by Sam stay producing over 200 tons of ore phich was mikled in the mill of the Eva Quarti Company on Ester Crepk. This/vein is a persistent regular to fissure striking $\mathbb{N}$. $15^{\circ}$ W. and dipping/steeply to the viest. The vein is cut by a system of step fautts stfiking $\mathbb{N}$. $30^{\circ}$. E. each of which has moved the north segpment of the vein a fer feet to the west. The vein ranges from a few inches tb over 2 feet in width. A $58 \cdot 20 \%$ William lic Conn and James Mclcann lessees on the Wandering Jew. claim ajoininE the First Chance vein at the head of St Patricks Creek discovered a vein vhich is probably the southest extension of the تirst Chance vein. A shaft 50 feek in depth was sunk with drifts 25 feet each vay from a point 30 feet in depth. Over 60 tons of ore vas mined from above these arift auring 1930. The vein strikes N. $_{4} 5^{\circ}$ E. and dips $60^{\circ} \mathrm{NW}$. The vein rapeg from a fer inches to over 2 feet in width of white crystalline quatz containing considerable needle crystals of stibnite with the characteristic Ereenish stain of the quartz ores of Ester Dome. 
$\mathrm{Kt}$

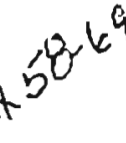

The kohawk lining company foperated throjghout about 10 months of the year with the mill in opefation soprevhat less, on a scale consistant with past operations. producer of the district has shown fairly regular production for a number of years. Irost of the ore minea during the past year was obtained from above the main tfonnel on the frohawk ivo. I vein. (A $25 \mathrm{Hp}$. Sirbenks-litorge deisej engine was installed in the fill during the summer which effepts a considerable saving in fuel, water consumption and in the officiency of mill operation.

A lease was let to Alfred.

Hightower on the Bondholder claim of the Wohavk Group. The Bondholder vein is a strong vein said to: carry a considerable width of medium Grade ore. It has been developea by several shafts and a lóng tunnel, alf of vich are nov caved. $k+5^{-3 y^{-}}$The Ixishman Eroup was worked in a small way during the year by Hugh vathieson and 0. M. Grant. 186 tons of ore produced, fas milled in the Ifohawk wining Compfny's mill. This property is the 10west in the district in elevgtion. The vein ranges from a few inches to 3 feet with an average of 88 inches in width. It is developed from a shaft 180 feet deep. $4+58 \cdot 15$ The sanford group was workeg/auring the year. Some ore was mined
but not milled.

$\mathrm{H}^{+}+496$ The Hiyi group was idle during the greater part of the year. It is now under Iease to Henry Feldman. A new Gibson balanced rod mill

a was being installed at the end of the year.at the mouth or the re in til Ri tunnel. The mill vill be driven by a small gasoline engine.

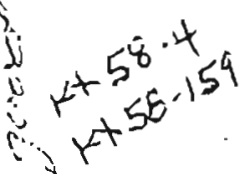
Sheelite Iungsten Claim the Sheelite claim, formerly the property of the Alaska Tungsten lines Company. The sheelite claim is located on the divide between the heaćs of gilmore Creek and Yellow Fup. A tunnel is to be driven tar witk the bottora of the 190-foot shaft. During the fiar period about 1,000 tons of ore was mined from inis property and silicaled in the mill which is situated on Yellos Fup. It is planred to increase the mill capacity page - 5 - 


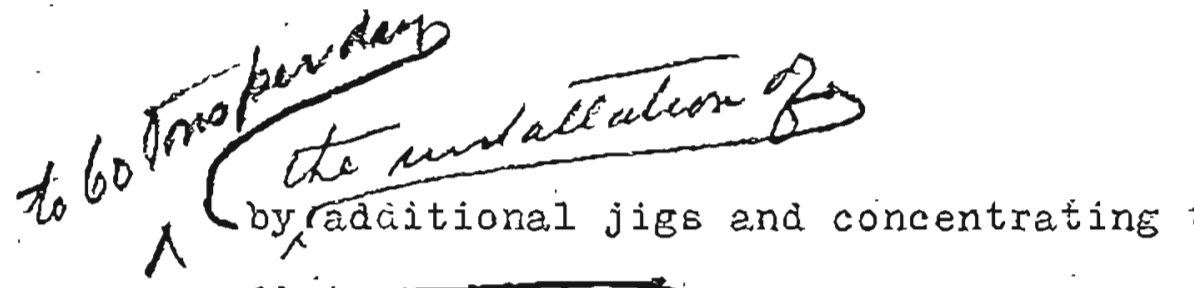

\section{0 per any.}

The vein has been previously descritud as ranging from 2 to

(W 12 feet in thickness, striking $\mathrm{N} \cdot 70^{\circ} \mathrm{g}$. parallel to the schistocity

7 of the country rock. The shaft following the vein dips at an angle of from $40^{\circ}$ to $18^{\circ}$.

Nenena District.

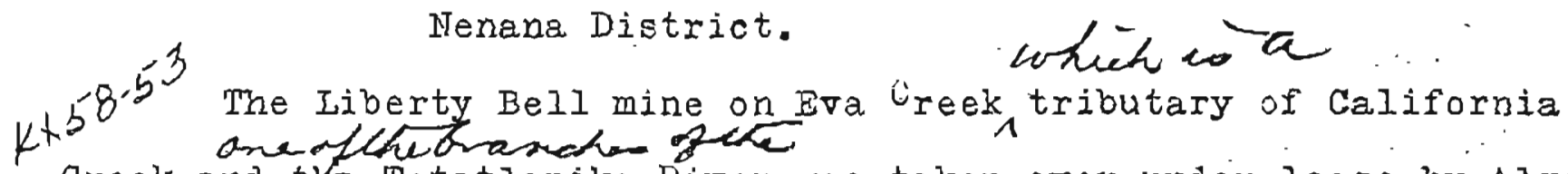
Creek and Totatlanika River, was taken over under lease by Algot Torbere, Justice Johnson, Oscar F. Prickson, and Bror Johnson. The deposit is a gold, arsenopyrite, quartz, busmuthinite mineralization in flat bedded schists. The mineralization in which the proncipal development has been done is in a clayey schist which ranges in dip from $\theta^{\circ}$ to $30^{\circ}$. The hichest gold values lie along the top layers close to a harder compact quartaitic variety which forms a roof or b hanging wall of the depositf. Ihe vertical range of this mineralization is not known but it is reasonable to expect other ore bodies is $\psi$ partly free, but a considerable proportion is enclosed vith the ? sulphides. Development pork cansists of a tumel 260 feet in length just above the creek level. This tunnel is ariven in a airection of 5. $5^{\circ} \mathrm{W}$. with a drift to the eastyor 135 feet and one to the west for 139 feet. Several hundred tons of milling ore recovered from the tunnel, drifts and 3 raises is piled at the portal or the tunnel. Eulenare urrecuse previous development have caved and are inaccessable. on the uniturlich is

The property is 11 miles from mile $371_{\Lambda}$ Alaska $K_{a i l r o a d}$ connected

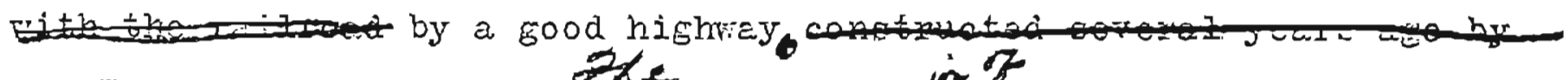

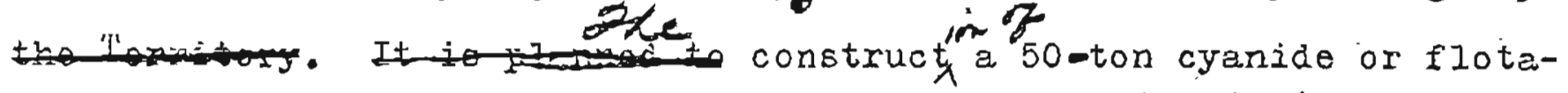
tion mill during the coming year is gelemed th the lewess..

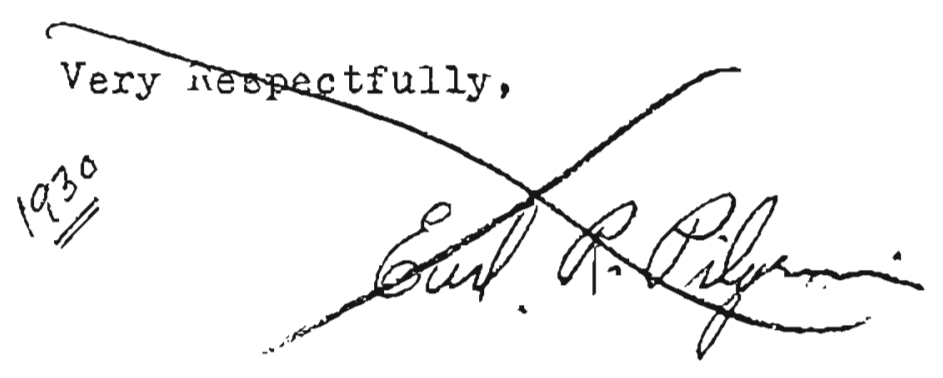




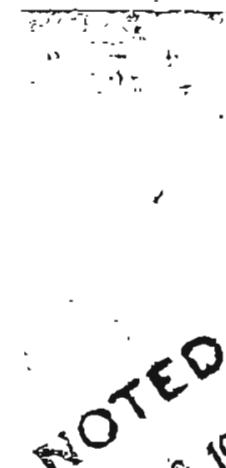

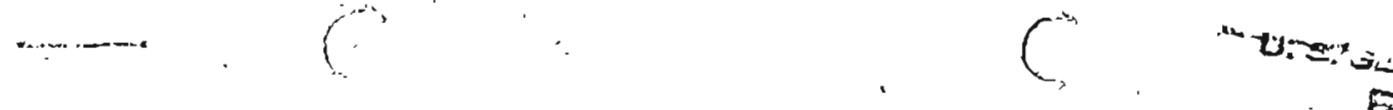

RECEMYEDURVY

Progress of Lode lining in Interior Alaska, 1931.JUN 271932

${ }_{3} 0^{13^{2}}$ the year was notable for a narked increase in production ALASKA. B. $D$ from the lodes of the Interior. All mines operating in 1930 ovening a number of ofder mines vhich had been iale for one or more years and some stimulus was given to new prospecting. Tro new properties came into production during the year upon the completian of milling plants; also two nev mills were placed upon older properties of the rairbanks Precinct. the lvabesna ines Corporation brought their property to the production stage with the completion of their concentrating plant during the sumer at Thite Iountain, Nabesna River Basin. The Eva Creek shining Company constructed a grinding and flotation vlant during the latter months of the year which went into production early in 1932. Tew discoveries are reported

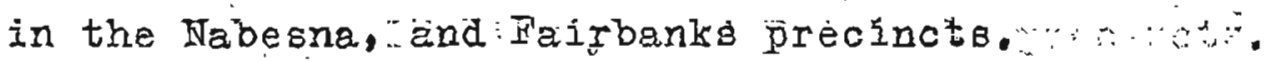

Falrbanks had the Ereatest lode gold production since 1935 and 1932 should equal if not exceed the production of 1931. A number of the mines show a reduction in operating costs effected through lower prices of foods and certain other supplies, and the installation of cheaper power, which in spite of the increased freight rates of the Alaska Railroad, shop a reguction from prices of previous yeara. Certain thems such as explosives are considerably ligher than they have been since the early days of the region.

Three of the older mines of the Fairbanks Precinct adopted deisel power for their plants. The saving in power costs can be rigured as $\$ 1,00$ per ton less, for milling costs, “ meking it possible to mine ores carrying that much less per ton.

For the first time in a number of yeare quartz mineng labor is plentirul. Alarger number are employed in the region than in a number of years but a large number have moved in frow mining districts outside the Territory who will undoubtedly become permanent residente of the Interior. 


\section{$\sum^{n}$ \\ General Sumary of Operations.}

Tairbanks Precinct.

\begin{tabular}{|c|c|c|c|}
\hline & 1929 & 1930 & 1931 \\
\hline Jumber of Fines Operated & 10 & 9 & 13 \\
\hline Number of Mills operated & 9 & 7 & 7 \\
\hline Tons oŕ Ore Hilled & $6,181-$ & 5,033 & \\
\hline Production & $\$ 83,500$ & 124,000 & \\
\hline Number of lien Underground & 41 & 32 & 43 \\
\hline Number of fien employed in rills & 10 & 9 & 13 \\
\hline Iumper of ken imployed Surface & 7 & 7 & 11 \\
\hline Total Number Bmployed & 58 & 48 & 67 \\
\hline
\end{tabular}

The above does not include about 6 or 8 individual prospectors developing veins in tine district.

\section{lines.}

$1+49-1 z$ The Cleary Hilis Alaska Mines Company operating the Free Golá vein on Bedrock Creek operated the mine continuously during 1931, furnishing steady work for a number of skilled workers throughout the year. This property again took first rans of gold producers for Iairbanks and became fourth largest producer of the gold lode mines of the Territory.

New developments have located the vein on the wiain Tunnel level which gives over 200 feet of depth now available in the new vorkings. A $100 \mathrm{H}, \mathrm{P}$. Washington $\mathrm{S}$. Step deisel engine was installed early in the year which drives the mill and a $45 \mathrm{KW}$. 60 cycle 440 volt generator which furnishes power for the compessor, pumps, and lights. Whis plant is the most modern and complete small plant in the Fairbanks Precinct.

$14+4 a^{6} 9$ The Hyoming line, on Jedrock Creek about 1,200 feet south of (Athe Iree Gold vein, was idle throughout the year except for about 60 feet of tunnel oriven at a lerel about 50 feet below the main tunnel to open up a parallel vein about 350 feet north of the Wyoming vein. सt 4 - 82 The Tolovana line vas operated only in a smali way during the year producing a fer tons of ore most of which came from the extension page $-2-$ 
found on the west side of Willow Creek.

$4 \times 44^{12}$ Tork mes continued on the Nemsboy rine at the head of Cleary Creek by the Niewsboy Development Corporation. Several hundred tons ô mill ore was blocked out for mining. 'In october the mill, whlch frad been reconditioned and a deisel engine installed for power, burned completely. Further prospecting rork has been resumed in the mine and it is planned to rebuild the mill as soon as net defelopments justify. It is also planned to unvater the lower workings and continue developments from there.

The mine plant is equipped with a 122 cubic foot Gardner- Denver compressor diredt connected to a Buick motor, and a Iidgerrood air hoist with drum 24. inches by 30 inches hoisting a 12 cubic root blicket with rope speed of 200 feet per minute.

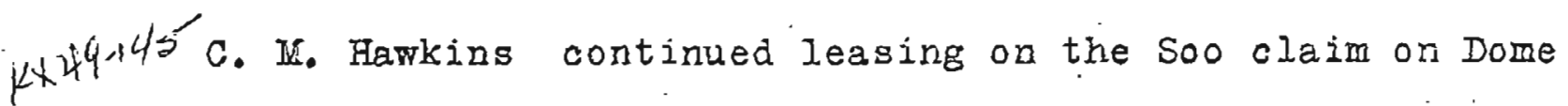
Creek. The Soo claim is a part of the old Spalding lrine group. Late in the year the two stamp mill was replaced by a 5 stamp D. D. Dernarest co. mill of 1,000 pound stamis with a 9 inch by 8 inch Colorado Iron Works Blake type crasher. The mili is powered by two Fairbarks Iforse Deisel engines, a 25 Horsepower: which drives the mill and compressor and a 15 Horsepower which drives a small direct current Eenerator to operate a tro stage centrifugal pump for mill vater. The purp is set at the 110 foot Level of the shaft on the Heath and Kerns vein. 111 ore mined aurinf the year was from above this level taken though a new slisft surk to a depth of 85 feet at a point 110 feet east of the main shaft.

fN44, 13 A leage tras acquired in the fall of 1931 by Harry Food on $a$ group of claims on Dome Creek consisting of the Frenklin, Wary, flpha, Omega, and Soo claims. A turnel was started fror a point near the southeast corner of the Franklin claim in a direction of $\mathrm{N}$. $6^{\circ} \mathrm{W}$. crosscutting the general vein system and expectins to.reach the Feath and Kerns, Wild Rose, and soo veins at a distance of orer l,200 feet. It is also expected that several other veins mill be crossed in the course 
of this tunnel which starts at an elevetion of about 1,228 feet and which will have a vertical depth of about 300 feet below the collar of the Heath and Kerns shaft on the Soo claim. The tunnel was in over 300 feet at the close of the year. $4+49.96$ of Henry Beldman was leasing on the Hi Yu Wine on Moose Creek Gíbson Balanced Roa mill wich ras installed late in 1930 at the routh of the main tunnel.

1449.201 Herbert Falkner and James wir were prospecting the North Star Ko. I 2 peins on the liorth star claim situated on the Wrest sicie of Skoogy Gulch. The North Star lo. I tunnel starting at an elevation of about 1,546 feet is driven in a direction of $\$$ 1T. $87^{\circ}$ W. for 155 feet, khich etyikes a z inch vein at a distance of a few feet in and follows it for the remainderof its length. The Quartz is white crystaline containing many drusy caveties and small amounts of sulphides. The vein aips about $83^{\circ} \mathrm{S}$. The wall rock is blooky quartzite for most of the distance in the tunnel except for the first 6 feet which is a mass of non porphyritic granite, farited into its present position. The tunnel vas ariven to open up a vein exposed in a shellow shaft higher up the slope and over 200 feet rest, Gaid to have a width of about 10 inches and to carry good $r$. values. The rein in the tumnel shows some goldralues.

A second tunnel driven from a point 125 feet south of the North Star vein No. I tunnel and slightly higher in eletation follorg a vein for about zo feet and crosses it diaconally. This vein is about 2 feet: in wiath of crushed brown quartz said to assay about This vein sirikes about S. $55^{\circ}$ W. and dips $43^{\circ}$ s. h second tein is encountered 30 feet in which strikes $3.83^{\circ}$ T. and stends vertical. Tlis vein is filled with white crystalline quertz somevhat crushed, banded and containirg considerable stibnite and arsenopyrite. The quertz is said to assay about $\$ 50.00$ per ton. A small tongue of granite shows in the face of the tunrel but is not cut oy the vein. The tunnel is in over 60 seet. Sẹveral tons of 
ore has been mined and sacked from this vein.

G. 0 . Warren was developing a group of 4 claims consisting $\partial^{3}$

f the Annie, Fary, Flsie, and Key claims on the ridge between and just abore the junotion of Iamarack and chatharo creeks. A shaft sunk or the Plsie claim from an elevation of 1,417 peet to a depth of 35 feet shows a vein about 12 inches thiok of dark sheared schist and quartz. The vein strikes I. $75^{\circ}$. TI. and dips $80^{\circ} \mathrm{S}$.

A few tons of ore recovered from this shatt was sacked Ior hauling to $\frac{d}{b}$ millag. About 95 feet east from this shaft and on the Liary cleim another shaft has boen sunk tọ a depth of 25 feet. This shait was inaccesable for examination but is said to show the same sheared zone with bunches of quartz containing considerable sulphider i.: galena, stibnite, and.arsenèpyrite, also iair values in EOId.

A tunnel has been driven from a point below the first shait and on the झlsie claim for over 60 feet wlich failed to locate a defirfte vein but shows much crgshed brecoiated waterial.

A $19.9^{3}$ की The Rex claim is situated on the west side of chathem creek about 2,000 feet above its mouth. This claim has been held for over 20 years by W. S. Reese and associates. A tunnel has been driven into the ridge in a general southerly direction crosscutting the trend of the veins of that section. This tuninel starting at an eleration about 100 feet above the creek bed encounters a vein 72 feet in, which strikes northeasterify and is said to average about 3 feet in width. Several tons of are milled from this vein a number of years ogo is said to have milled about $\$ 8.50$ per ton. The vein was not open fot examination when visited by the Friter. At a distance of 258 feet in the tunnel a iauit is encountered siriking $5.60^{\circ} \mathrm{W}$. A branch of the tunnel follows the fault for over 45 feet and at a point a fer feet from: the face a quartz stringer shors on the west wall striking almost mest and dipring $45^{\circ} \mathrm{s}$. This stringer is about 3 inches thiok of crystalline quartz which pans some free gold. The other tranch of the tunnel is driten south for almost 100 feet through a blocky schist. 

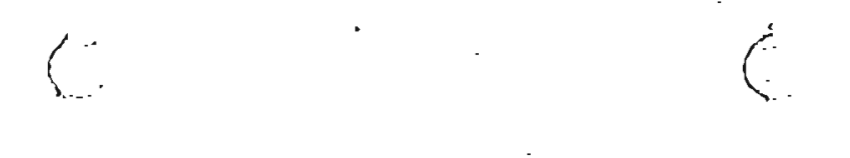

About 40 feet in from the two branches of the tunnel a stringer shows crossing with a strike of $7.75^{\circ} \mathrm{E}$. and dipping $25^{\circ} \mathrm{S}$. This stringer is about 3 inches thick of white crystaline quartz which also pans sone Iree sold.

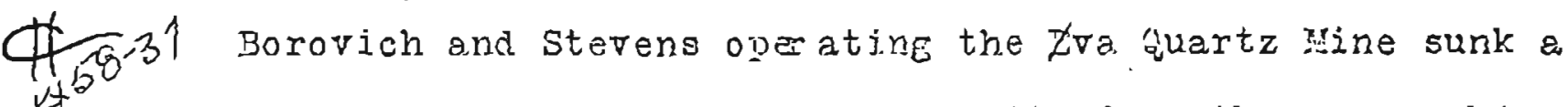
large number of shafts and pits with drifts from them, searching for a vein from which $2 \frac{1}{2}$ tons of float was found. This float vas very high grede and several $v \in$ ins were discovered in the search but vere not believed to be the vein throwing the rich float., one shaft visited by the writer sunk from an elevation of about 1,175 feet and aoout 300 feet east from the portal of the ara quartz Company's lonee tunnel, and 40 feet deep, shored a vein from 16 to 24 irches in wiath, striking $\mathrm{N}, 2^{\circ} \mathrm{W}$, ard dipning $750 \mathrm{~T}$. of brom stained guartz containing inuch schist breccia. The schist vallrock stands almost.vertical. It is a decomposeo, altered porphyry.

Roy Caldart and Andy Karkich were leasing during the year ón the Eva Creek Group, Droducing over 300 tons of ore which was custon milled. 'Most of this ore was recovered from the tunnel which was extended through the. Little Dra claim and into the Blue Bird claim. A 40 foot crosscut tunnel wa driven east in an endeavor to locate the southern extension of the vein which was found to te faulted fust south of the main tunnel portal. A shaft was sunk 45 feet and a crosscut driven 20 feet irom the bottom. Another crosscut was driven 60 feet from a point in the main tunnel and two winzes sunk 30 feet and 40 feet in depth were sunk from the main tunnel.

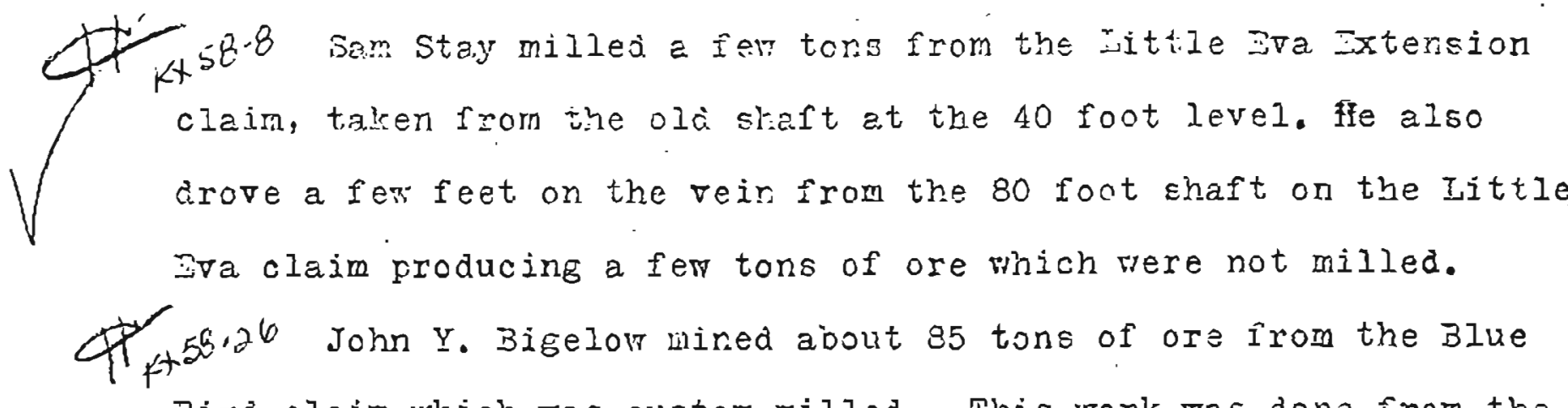

Bird claim which was custom milled. This work mas done from the 


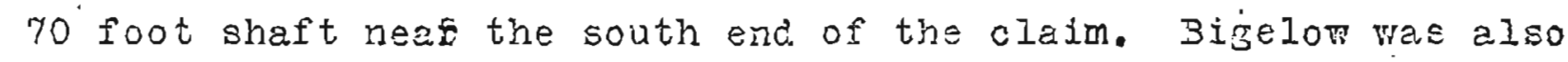
norking on the Iving clain arifting frou the bottom of a 5 foot Whaft into a Eranite porghyry dike which is said to carry values in sold. The Iving claim is aituated just neat of the Ryan rio. 2 claim. A tunnel was also driven 268 seet in a northerly direction of the frarion claim in a search for a vejn froin which a large quartz boulder of rloat weighine over a ton was found. Tho crosscute from this tunnel, 13 Ieet 210 io 30 feet have been ditiven. The Larion claim lies east of the voDorald claim.

$456,2^{08}$ the Clipper cliein part of the st Paul group lies across $x^{+}$Pra Creek about 2 miles above ite pouth. At an elevation of 1,118 feet a tunel was juiven fron a point close to the creek into the hill in a direction of $S .85^{\circ} \mathrm{E}$. for about $2 \Delta 5$ feet crosscuttins the trend of the veins. At a distance of about so feet in, a vein striking $\mathrm{N} .4^{\circ} \mathrm{E}$. and dipping $80^{\circ} \mathrm{E}$. has been folloved with a drift which was in 35 feet Januory 13, 1332. The vein shows from 4 to 12 inches wide vith an average of about 8 inches of frey crystaline quartz containing slizht sulphides. The vein is said to carry fair values.

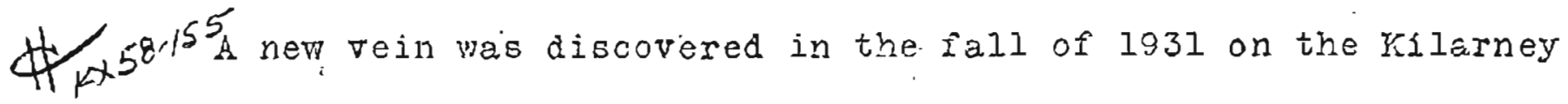
claim of the st paul group. This discovery is about 500 feet from the north end line of the claim which is located on the ridge betweenriva $C_{r e e k}$ and St Patrick Creek. A shaft sunk on the vein Irom an elevation of about 1,432 feet rias idoma $4 Q$ feet on January 13,1932 and about 15 tons of ore on the dump. The rein shows about 12 inche of vitreous, greenish stained quartz, containinf some sulphides. The vein has a strike of N. $5^{\circ} \mathrm{E}$. and dip of $75^{\circ} \mathrm{W}$. The ralls are light colored micaceous schist jipping gently to the east.

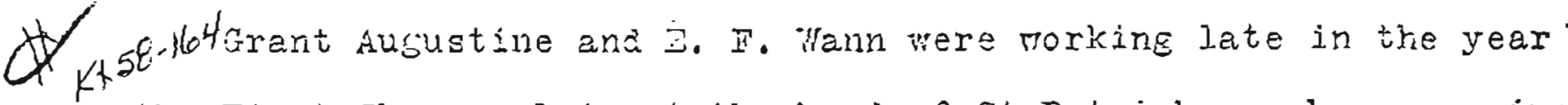
on the Iirst Chance claim at the head of St Patrick creek, reopening the upper tunnel. $W_{\not+} 58.69$ The lohatk Inining company operated throughout the year. ore
page -7 - 
Was mined from the fohark lTo. I vein above the main tunnel level and from the Bondholder vein. Leasers were working during the vinter on both veins. A new shaft pas sunk on the Bondholder vein from $\theta$.: point several hundred feet south of the old shafts. This. shaft pas down about 40 feet January 13, 1932. Leasers were planning on sinking the shaft deeper and opening up a stope from there. This new shaft starts at an elevation of about 1,315 feet. The vein has a strike here of N. $28^{\circ}$ E. and a dip of $40^{\circ} \mathrm{W}$. with a vidth of from 6 to 10 feet of crushed quartz and country rock.

化 58.145 Jess Sanford operated alone throughout the year, producing some ore which ras not milled.

man Group. About 1 co tons of ore was mired and custom mileed which returned about $\$ 15.00$ per ton. This ore vas mined from above the 180 foot level which is slightly above water level. The 180 foot level is about 86 feet into bedrock on the vein with an preburaen of about 94 feet. This level pas extended south from the shaft to a total length of about 250 feet. Itjis planned to sink a new ehaft about 500 feet south of the present morking shaft.

4 $1<58-244$ W. P. Borden and sd Quinn were working on the American claim / situated on the divide between the heaòs of Pearl Creek tributary of Fish Creek and Victoria Creek tributary of Smallwood Creek. A shaft sunk a number of years ago from an elevation of 1,733 feet said to be 70 feet in depth was on a vein said to be from 18 inches to orer 7 feet in width. The vein strikes about $7.56^{\circ} \mathrm{E}$. and dips $62^{\circ} \mathrm{NW}$.

About 400 feet fiortheast from this shaft and at an elevation of 1,634 feet 2 tunnel was driven in a Eeneral southvest virection in an endeavor to pick up a pein whose float was fount in considerable quantities alone the cosrse of the tunnel. The tunnel however feiled to locete the vein rhich is probablgaferther west. This tunnel was in 160 feet Tune 2, 3932, and about 75 tons of ore piled on the dump. Either the rein up hill which has the shaft on it is a different veir from the one whose float is found in the tunnel or it hes been faulted some distance. The ores from this vein shors much sheelite wixed rith Dage - $8-$ 
quartz. This property is within the scheelite belt of the district and only about $I$ mile from the scheelite and Tungsten claims at the head of Yellow sup.

Respectfully Submitted, June, 5, 1932. Fairbanks, Alaska.

Associate Territorial Mining Engineer..

page $-9-$ 
Progreas of Lode Mining In Interior Alaska.

Iode mining was carried on in the Interior of Alaska in 1932 at about the same rate as in 1931. All mines which operated in 1931 were working in 1932: Inadaition there was some activity in reopening mines which had been closed down for some time and work was done on several new veins. One mill was dismantled and moved to a new location in the Fairbanks preoinct. The Eva Creek Kining Comany operated the Liberty Bell mine and conoentrator, throughout the season shipping gold flotation concentrates to the Tacoma Smelter. The Nabesna Hining Corporation operated throughout the season which was short but highly successful. New discoveries are reported in the Nabesna, and Fairbanks precincts. Gold production of the Fairbanks precinct was about the same as during 1931 although a production resulted from a larger number of operators. Also a substantial greater number of men were employed in the precinct. The cost of mining is still affected by the high rates for freight on the government owned railroad on coal, o1ls, gasoline, explosives, lumber and foodstuffs. An encouraging announcement was received late in the year authorizing the management to lower freight and passenger rates, when deemed advisable; to the older rates existing prior to 1931. It has been found possible under the present rates to ship explosizes and other commodities by truck over the Richardson Highway in sumer at a considerable saving.

Lobor was plentiful for mining during the year. Wages remained at the customary level for the camp. Lode miners were paid $\$ 600$ and board per 8 hour shift. This is considerably higher than along the coast. liost of the mines operate seasonally and therefore cannot insure steady work except for posibly one thire of the total number employed. A number of men employed during the surmer season in connection with placer mining are found in the winter engaged in prospecting or developing quartz. This creates an overlapping in the tabulation of labor data for the Fairbanks precinct. page -1 - 
General Summary of Operations. Fairbanks Precinct.

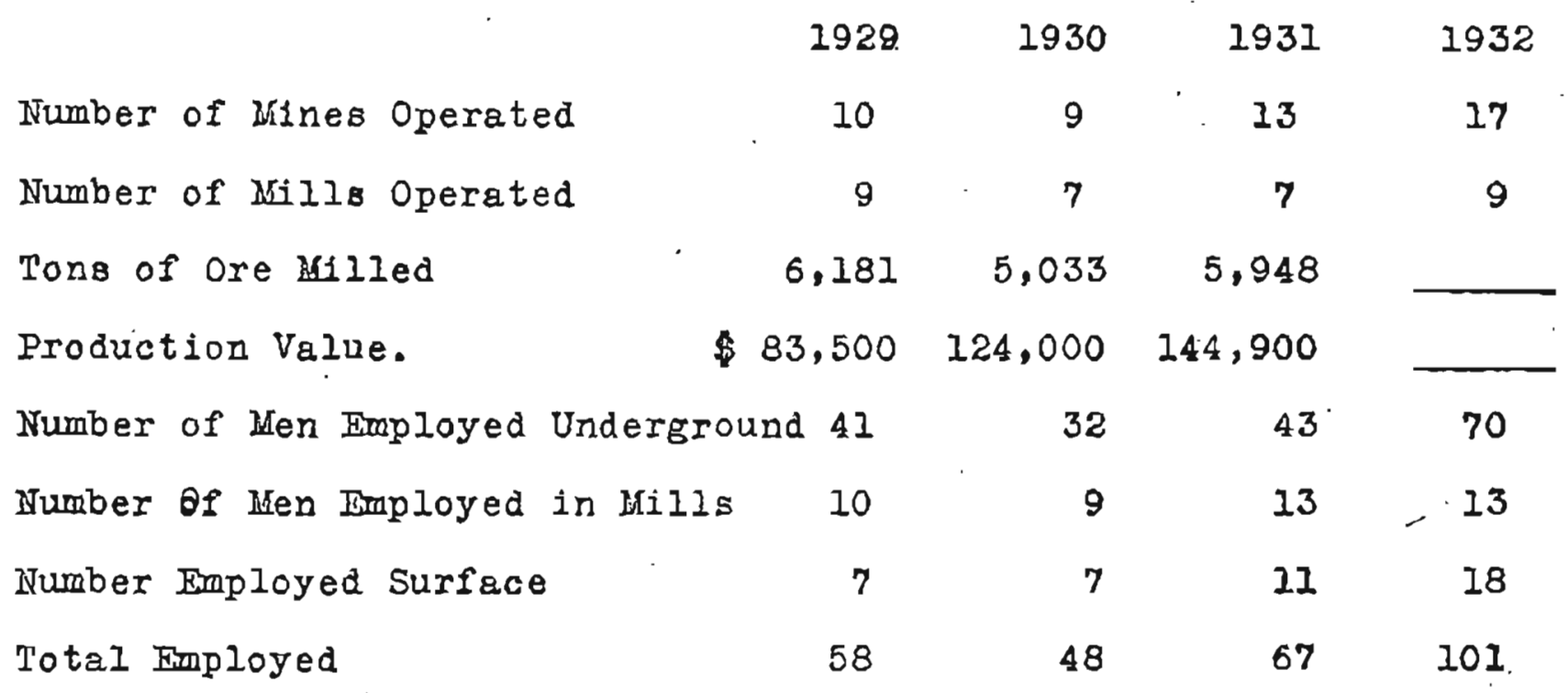

The above does not include about 6 or 8 individual prospectors developing veins in the district or labor doing annual assessme ent work on idle property.

\section{Mines.}

14H411 The Chatham mine located neas the head of Chatham Creek and which has long been idle was leased lote in the year to Herb Miller, and assooiater. A $\dot{i}$ Torl was started on a crosscut tunnel which it is belleved will strike the lead at a distance of 550 feet in and givea depth of about 120 . feet below the main tunnel which is also a crosscut tunnel. The vein strikes about N. $60^{\circ} \mathrm{W}$ and dipo about $70^{\circ}$ S. It is reported as having an average width of about 12 inches. The property has had a considerable past production from ore which was hauled to the mill consigting of 2 unitg of 2 Joshua Hendy 1,000 pound stemps, situated about a mile from the mine and in Chatham Creek.

A. F. Lathrop and associates took a lease and option lete in the year upon a group of clalma from Lev Colbert and George Warmbold. These claims are on the Tamarack Creek tributary of chatham Creek and lie along thie south slope of Chatham Creek. A tunnel started in October was in 550 feet on Feb. 8, 2933. This tunnel Was started at an eleration of 1,295 feet and is being oriven in a direction of $37^{\circ} \mathrm{K}$. to crosscut 3 veins which outcrop on the surface. At 380 feet in a vein is crossed which strikes northwest or at about 900 from the tunnel and dipe $28^{\circ} \mathrm{S}$. This vein is repe. page - 2 - 
prted as dipping $45^{\circ}$ on the surface. It shows in the tunnel about 5 inches of crumbly ground quartz which is said to pan considerable gold. The quartz is browghtained showing no sulphides.

A small stringer linch in thiskness shows cutting across the tunnel at a point 175 feet in. which is said to pan a little gold. This stringer strikes N. $48^{\circ} \mathrm{W}$. and dips $53^{\circ} \mathrm{S}$. A fissure shows cutting the tunnel at a point 240 feet in whioh is filled with gouge and brecciated schist. This siop is reported as not panning. It is believed that the tunnel is considerably past the point, where is presumed that they either have flattened out greatiy or are cut off by a fault.

A small Gardner Denver 119 cubic foot compressor alredt oonnected to a Bulck motor furnishes air for the tunnel driting. An Ingersol Rand $12^{\prime \prime} \times 10^{\prime \prime}$ type $F$. R. compressor has been moved onto the ground which wiIl we driven by a 75 Hormepower Fairbanks Morse 2 cyele 11 engine.

$4+49,26.96$ The Clears Hills Alaskalines company operated continuously durins the year. The mill was operated about 7 months and a small crew was kept developing during the remeinder of the year. Recent operatiobs have brought the present mining to below the main tunnel. Some work was done during the year on the 70 foot level which is 70. feet below the main tunnel or about 390 feet below the highestipoint on the ridge between Bedrock and Chatham creeks where the vein crosses. Plans are considered to drive a stili lower tunnel starting from a point downstream which will give a possible ro feet additional depth. Unless this lower tunnel is driven it will be necessary to pump a large ciflow of water which was encountered when the winze was sunk in 1913 to a depth of 140 feet below the main tunnel and levels run out on the 70 and 140 foot horizons. A later shaft sunk in the footwall also showed extensive water.

49,231 Charles Holke started work late in the year on a group of claims extending across Chatham Creek and including property originnally covered $b_{y}$ the old Ploneer und property. 
It is said thet éarly operations on this vein showed it to be in a block of ground probably broken off from its original position and turned over to a flat lying position. It is plannea by the present leasers to reopen and develop this property which at one time had a 5 stamp mill and is said to have produced several thousand dollars in bulizion.

ik $14^{-2 k}$ ine Wyoming mine was idle throughout the year. It is reported that attempte are being made to reorganize and finance this property.

$1444-8 \%$ The Tolovana mine was operated in a small way during the year. Plans are now underway to ship a few tons of high grade ore in which the Ereater portion of the valuos are said to be locked up in the sulphides, which consist of arsenopyrite, stibnite, pyrite, galena and tetrahedrite.

K $49-12 g$ Development work continued throughout the greater part of the year on the Newsboy Mine at the head of Cleary Creek, by the Newsboy Development Corporation. A new 180 cubic foot SuIlivan compressor driven by a 25 horsepower deisel engine has been installed. at the mine which furnishes air for arlling, hoisting and pumping water. It is planned to install a new electric driven triplex pump in the near future. Diring the year 150 tons of ore ras hauled 7 miles by truck to the Tom Gilmore mill on Fafrbanks Creek and milled This returned slightiy less than $\$ 20.00$ per ton. In February 1933 the 215 foot level was being reoperied and it was planned to carry on exploration work on the level north of the fauled region which has cut of the vein in that direction. Leasors were sinking a shat on the Robinson vein on the riewsbog claim. The shaft was down about 30 feet and it was planned to sink to the 50 foot level and then drift. A small surface cut on this vein is reported as hasing produced 35 tons of ore a number of years ago which milled up about \$35.00 per ton. The rein shows in the above shaft about 800 feet northeast of s:: the versboy shaft and is striking about $\mathbb{N} .80^{\circ}$ F. and aipping $70^{\circ} \mathrm{s}$. The ivewsboy rein strikes N. $42^{\circ}$ E. and dips $73^{\circ}$ W. The Iewsboy kxtension vein which is exposed in a shaft 300 feet northeast of the page - 4 - 
the Newsboy shaft strikes N. $15^{\circ} \mathrm{F}$. A continuation of the Robinson vein with its apparant strike would aause it to intersect the Newsboy and Niersboy Fxtension veins at points approximately 200 feet north of the Newsboy shaft. wo evidence of this shows in the under- $:$ fround workings and it is probable that the Robinson vein will be found bending until it is perallel to the lyewsoby vein. It has probably been effected by some relationship to a soft basic intrusive rock which has been found outaropping at points nottheast of the surface cut and towards which the vein points.

The Robinson vein has a width of from a few inches to over 2 feet with an average of about 10 inches of white crystalline quartz containing considerable arsenic and antimony sulphides. There is about $\frac{1}{2}$ inch of gouge along both wails.

1444145 The C. M. Bawkins lease was operated until september 1932 on the Soo claim on Dome Creek. When work ceased the mill vas dismantled and moved to the Andy Harkich property on Ready Bullion Creek. All ore produced from the soo claim during the gear was obtained from the block of ground measured from 100 feet douth of the Heath and Kerns shaft to 200 feet north of it and from above the $110^{\circ}$ fot. level. Ail ore was obtained from the Heath and Kerns vein. Hy, iz The Harry Wood lease on the soo claim and adjoining claims 1 was continued by driving the tunnel, started during the year previously, to a depth of 850 feet, where a vein believed to be the Heath and Keins vein was encountered. A drift was driven eagt on this vein for a distance of 50 fett and 2 short raises run up. The vein in these raises shows a width of from 10 to 16 inches of brown oxidized quartz which is said to carry good values. It is planned to install a 2 stamp Nisson, 1,350 pound stamp, mill near the portal of the tunnel early in the Bpring.

A 4 - 4 L Iate in the year a lease and option was taken on the Hi Yu mine,better known as the Crites and Feldman mine, by the Gustaffson Brothers ( of the Cleary Hills Alaske Mines Company) Joe Crossen and Ed Young. During the winter of 1932-1933 2 men were employed with development work preparing to drive a raise from the main tunnpage $-5=$ 
el to the upper tunnel to prospect the ground between. Orer $\$ 100$, 000.00 was produced from a shoot of ore above this upper tunnel and it is believed the ore should be found raking down below the tunnel and the ratse should intersect it. There is a vertical distance of 200 feet between these tunnels and 250 feet between the main tunnel and mill tunnel. The upper tunnel is in about 1,200 feet while the main tunnel is in 1,525 feet.

$4+49-103$ Leasers commenced work on the \#enry Ford group or Ho Carty mine at the head of Fairbanks Creek. They were preparing to oink the main shaft of the lic Carty vein, which is at present 80 feet, to a depth of 150 feet, and extend drifts from this new horizon.

1449136 William Fightower and associates started work late in the year on the David olaim of the Rainboy mine. They had started to sink a shaft at the portal of the. Rainbow tunnel on Feb. 1, 1933 to prospeot the vin below the tunnel level. The main shaft extends to a depth of 40 feet below the tannel but is at present inacesibjea because of ice filling the tunnel from seepage water. The permanent water level is about 10 feet below the tunnel flood. $k+58-16 k$ C. M. Hawkins leased the Andy Markich group consisting of the Fairbanks Lode No. 1 and No. 2 claims in September. This property is situated about $1 \frac{1}{2}$ miles above the mouth of Ready Bulliod Creek. (This property was described in the Report of 1930 as the Radovich group.) A small amount of development work was done by driving the lower tunnel about 75 feet ahead and 2 raises extended into the vein. The mill moved from Dome Creek was set up and about 750 tons of ore put through late in the year, which returned low values. Wost of this ore was obtained from both sides of the winze below the upper tunnel. The upper tunnel is about 130 feet higher in elevation and about 170 feet south of the lower tunnel. The lower tunnel ifarts at an elevation of 1,180 feet and is in dibout 545 feet. Above the lowe tunnel an page $-6=$ 
intermediate drift 75 feet in length extending south from a point below the winze, was driven and most ore milled during the season was obtained from above, Hater was encountered in this drift which colpled with the soft gouge and brecciated rein filling, caused by stivike faulting, gave much trouble on account of a swelling hanging wall. It is planned in future mining to keep the drifte well into t... the foot wail.

The mill consists of a battery of 5 D. D. Demarest Co. 1,000 pound stamps, with amalgamation plates 5 feet by 6 feet and a battery of 2 Joshua Hendy stamps with plates $2 \frac{1}{2}$ feet by 6 feet both driven by a 25 horsepower Fairbanks Morse deisel engine. A 15 horsepower deisel engine of the same make is beited to a direct current generator which furnishes power for lights and pumping water for the mill. The mine is equipped with a 110 cubic foot Rix portable type compressor driven by a Fordson tractor. Buildings consist of a log cabin residence, frame bunk house, mess house and mill.

9 $<+50-37$ Borovich and Sterene at the Era Quartz Wine continued the surface prospecting of the mineralized area south of the underground : : workings and along the strike of the mineralization. $y$ About is surface shafts were sunk during the year with about 150 feet of drifts and crogsouts from them. About 40 feet of raises were driven above the lower.tunnel. When visited Feb. 4, 3933 a cross cut ras being driven from a point 120 feet in the lowex tunnel, east to connect with the ex.i series of surface holes. This will connect or crosscut the mineralized area for a width of over 400 feet which from work to date shows values of from a few cents to orer $\$ 30.00$ per ton. About 60 tona of medium grade ore was milled from the property during the year and about 110 tons of custom ore was treated.

K T $^{58-8}$ Roy Caldart and Andy larkich leasing the Little Eva Group produced $56 \frac{1}{2}$ tons of ore which returned 34.00 per ton. This ore was custom milled. The ore was recovered from the south end of the Little tra claim south of the Sam Stay tunnel. $4+5$ f. 26 John $Y$. Bigelow and $\mathrm{H}, \mathrm{T}$. Jeppeson leasing on the McDonald 
claim of the MoDonald group sunk a nEw shaft about 40 feet north of the old cared licDonald shaft on the Mc Donald vein. This shaft had reached a depth of 60 feet on the incline when visited Feb. 4, 1933. The vein shows striking $\dot{N}$. $15^{\circ}$ W. and dipping from $30^{\circ}$ at the surfaoe to $62^{\circ}$ in the bottom of the shaft. The vein has a width of from 6 inches to over 2 feet of quartz lfying in one or more bands with an inch or more gouge on the walls and also in the $\because . .1$ Tein between the quartz bands. The vein filling includes a considerzble amount of sulphides principally arsenopyrite. The quartz is dense dull fine grained varying in color from white to dark green fím the oxidized arsenic minerals. The wall reck on both walls is a soft gray intrusive, probably granodiorite.

A lot of several tons of this ore when milled a few tears ago was found to have over half of the gold values locked up in the sulph: a ides incapable of being amelgameted. A lot of 54 tons mined during 1932 pas milled in the Era Quartz m111 and returned only \$11.00 per ton in free gold amalgamated. Anothar lot of $31 \frac{1}{2}$ tons of ore was shipped late in the year to the Tacoma Smelter. A return of $\$ 40.47$ per ton тав recaived although there is only slight profit shipping this grade of ore after frefght, penalties on account of arsenic and antimony, and treatment charges are deducted.

The smelter analygigon this lot is hore given:

$\begin{array}{lccc}\text { Al2 } 03 & 1.3 \% & \text { Antimony } & .46 \% \\ \text { Iron } & 8.9 & \text { Si } 02 & 60.00 \\ \text { Arsenic } & 10.59 & \text { Ce } 0 & \text { trace. } \\ \text { Sulphar } & 1.2 & & \end{array}$

The freight on a shipment of ore from Fairbanks to the Tacoma suelteris $\$ 12.00$ prr ton. Treatment charge for an ore velued at 40.00 is 6.50 per ton. The penalty is 25 cents per unit for contained arsenic and antimony. H. $45.20^{8}$ Iohn Mikely drove the north drift of the clipper vein ahead about 25 feet as annual assessment work. He was starting a lower
crosscut tunnel to strike the vein at a depth of 60 feet below the
present crosscut tunnel. 
4

W. D. Thomas and brother worked throughout the year on the véin found late in 1931 on the Kilarney cla1m of the St. Paul group the working shaft was sunk to a depth of 94 feet and a drift turned off both north and south. The north drift was driven about 60 feet to where a fault was enoountered. This ladt was not open for examination by the writer but it is probable that the vein will be found to the east as other faults in the vicinity throw that direcrzon. Ine souin oriti pas extenaea Ior a aistance or about 165 feet. An intermediale drifl was ariven at a aepth of about 30 reet norin to the fault.

About 180 tone of ore was mined and milled from the vein during the reason and milled in the st. Paul mill.

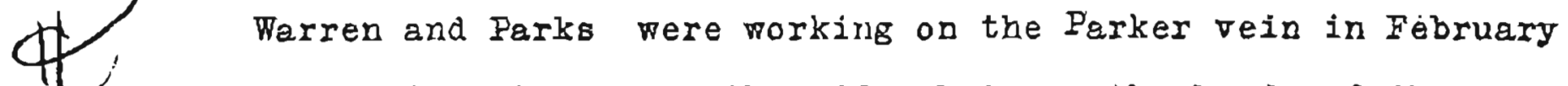

1933. This vein outorops on the ridge between the heads of sheep and Nugget creeks. The vein was discovered a number of years ago and was opened byimeans of a number of open cuts and a shaft 70 feet on the incline. The vein shows in the shaft as a small irregular lead from Ito 6 inches wide of white coarsely crystalline quartz containing swall amounts of sulphides. The vein strikes $N \cdot 15^{\circ}$ E. and dips about $55^{\circ} \mathrm{W}$. A few tons of ore obtained from sinking the shaft and from surface pito was milled in a test mill in Fairbanks and milled up over 80.00 per ton. The present leasers are drifting both north and south on the lead from $e$ depth of about 50 feet in the shaft. 4 f $458-14$ sess sanford was sinking a new shaft on his property at the head of Iittle Dome Creek tributary of Sheep. Creek preparatory to taking out ore.

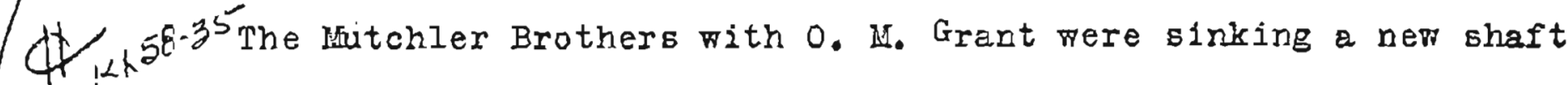
on the Irishman No. I claim 500 feet south of the main shaft. A lot of 75 tons of ore produced during the year was custom milled and returned about $\$ 15.00$ per ton.

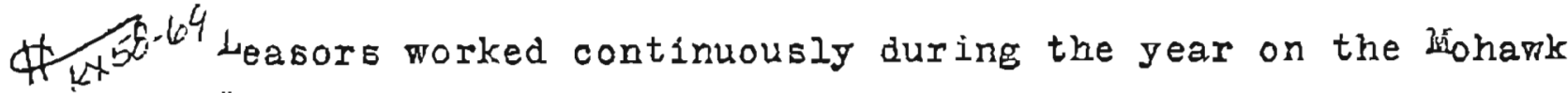
Mining Company's property at the head of St Patrick Creek. Two men were working on the Bondholder vein. and tpo men on the Iittle Wohawk 
vein. The latter did not produce mill ore during the year. All ore from the lohawk and Bondholder veins was milled in the company mill.

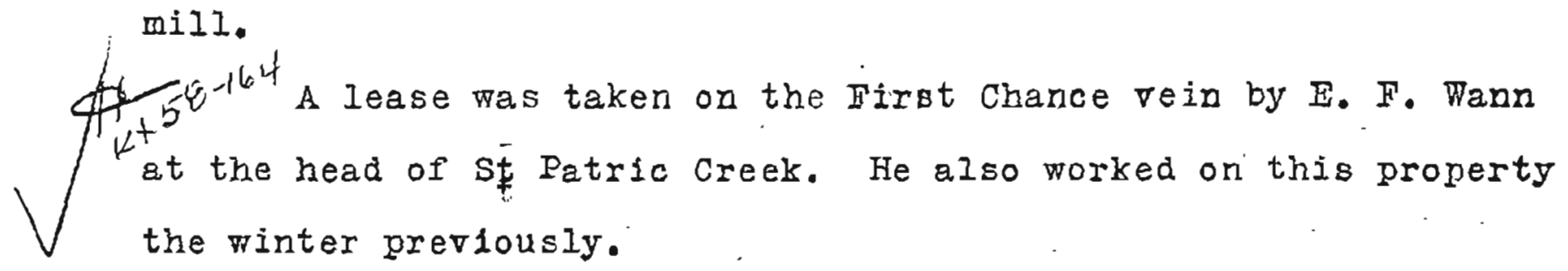

Respectfully Submitted,

Fairbanks, Alaska.

Feb. 13, 1933.

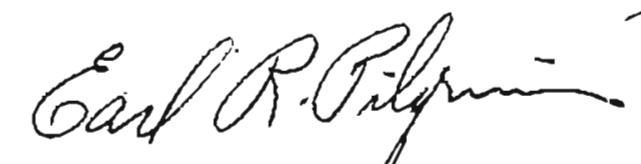

Associate Territorial rising Engr.

page - 10 - 


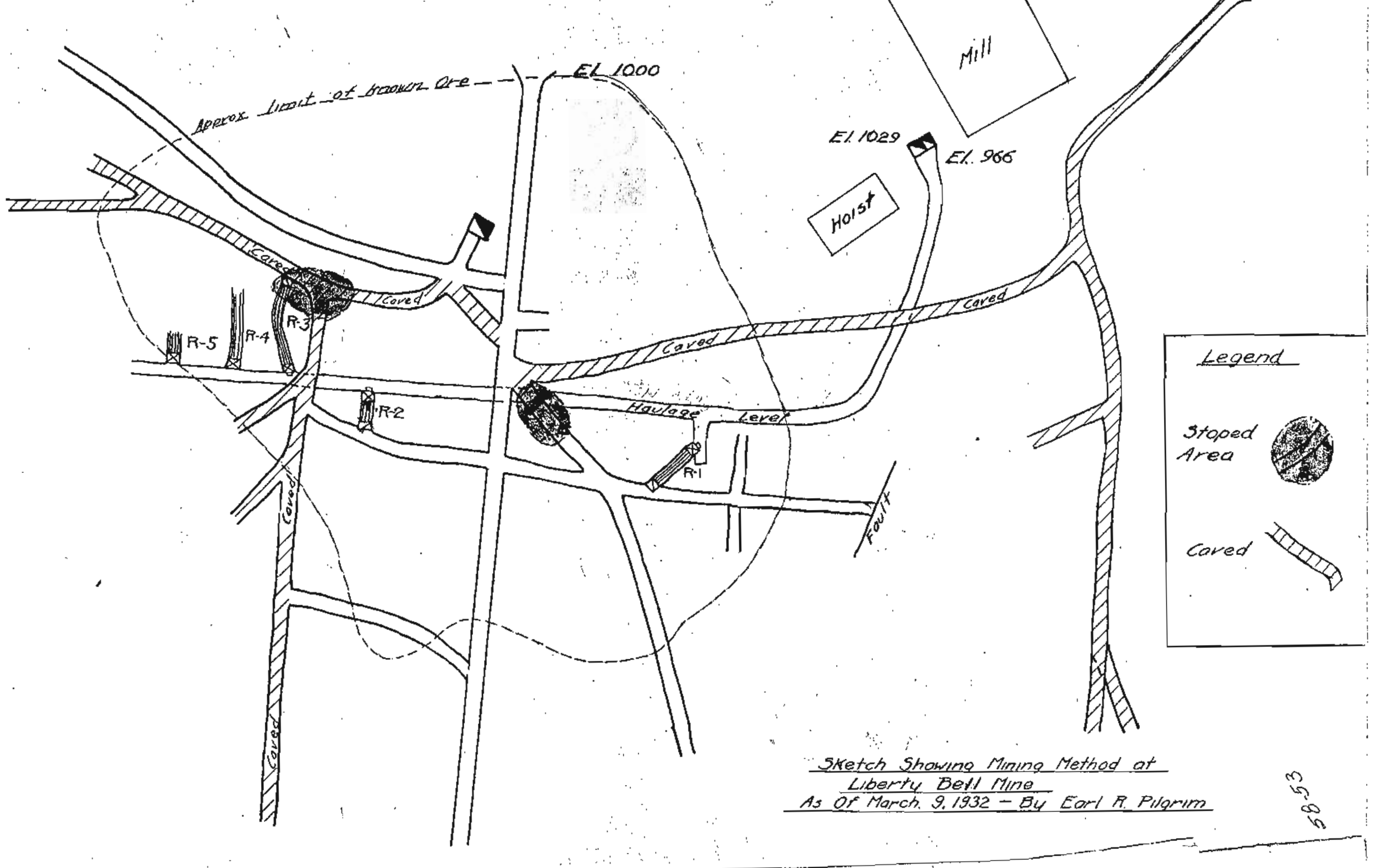

